\title{
THE EVOLUTION OF FISCAL PRESSURE IN DEVELOPED E.U. COUNTRIES AND ITS DETERMINANTS
}

\author{
Raluca Andreea GHETU1', Cristina-Simona CĂPĂȚîNĂ ${ }^{1}$, Petre BREZEANU² \\ ${ }^{1}$ Doctoral School of Finance, Bucharest University of Economic Studies, Bucharest, \\ Romania \\ ${ }^{2}$ Phd Professor, Department of Finance, Bucharest University of Economic Studies, \\ Bucharest, Romania \\ gheturaluca93@yahoo.com \\ capatinacristina12@stud.ase.ro \\ petre.brezeanu@fin.ase.ro
}

Abstract: Since 1970, the intensity of implementing budgetary policies in the two categories of states, developed states, and emerging states, has been observed in Europe. These policies had the effect of increasing the levels of taxation, also called progressive taxation, at that time. To stop this phenomenon of progressive taxation, the Maastricht Treaty and then the Stability and Growth Pact have had the effect of forcing states to adopt different fiscal policies to reduce the feeling of fiscal pressure made necessary by budgetary deficiencies and public debt accumulated over time. In fact, since the 1990s, each Member State of the European Union has interpreted the treaties mentioned above separately; some states reduced spending, while others preferred to impose more significant fiscal pressure on citizens by raising taxes and fees.

In our article, we analyze and disseminate the general fiscal pressure of some developed countries in the European Union. We identify the economic priority indicators that influence the phenomenon of fiscal pressure, such as the level of direct taxes, indirect taxes, the growth rate of gross domestic product, and the level of public debt, providing an overview of economic development over the last three decades.To this end, the authors have developed an econometric model that captures the factors that influence the fiscal pressure in several developed countries of the European Union in the period 1995-2018.

Keywords: fiscal pressure; tax evasion; direct taxes; indirect taxes; public debt; GDP growth rate

JEL classification: H26; H71

\section{Introduction}

Taxes and fees represent a significant source of state budget revenue, indispensable for any state. What is the tax, and what is its power and role in the economy? The literature shows that the tax is defined as a mandatory financial tax imposed on a taxpayer by a government organization for government funding (Charles E. McLure Jr., 2015). This shows that the payment of taxes by taxpayers to the government is mandatory to increase budget revenues.

A definition found in the literature, "taxable income is the income remaining after deducting the costs of the production and business process" (Nguyen Huu Cung, 
2015), shows that the phenomenon of fiscal pressure is indispensable in an economy. The fiscal burden on the economy is inevitable, the essential aspects being related to the citizens' resistance to this phenomenon and the governors.

The scientific and conceptual approaches to pressure were explained over time. According to the literature, fiscal pressure represents the tax burdens on the shoulders of citizens, with a risky and high endurance (Talpos and Enache, 2001; Brezeanu, 2009). Since this phenomenon arose, specialists worldwide have been looking for economic measures and policies to reduce the harmful causes of rising tax levels. Therefore the fiscal pressure is of global interest to all specialists.

According to the literature, in the case of developed countries, policies have been adopted to relax tax burdens, with various measures to change or move the levels of progressive taxation on direct taxes, to reduce the phenomenon of fiscal pressure. Many authors have shown that, since the 1990s, developed countries have reduced the tax burden on indirect taxes (value-added tax, excise duties) but increased the level of the direct tax burden (income tax, corporate income tax, income tax on micro-enterprises, and others)

This study is conducted to show the level of general fiscal pressure, direct and indirect taxes in developed countries, compared to the average level of the European Union. Also, essential factors in dealing with any issue related to fiscal pressure are the level of public debt and the annual growth rate of gross domestic product. The first part of the article provides an overview of several seven developed countries in the European Union, analyzing fiscal pressure, direct taxes, indirect taxes, public debt, and the growth rate of gross domestic product. Developed countries were chosen according to geographical location. We focused on three states north of the European Union, Sweden, Finland, and Denmark. In Western Europe, we chose France and Spain, and in Central Europe, we chose Luxembourg and Germany. The final results are compared with the average level of the European Union. The comparative analysis is examined every five years, starting with 1995.

In the second part of the article, we present and analyze multiple regression, having as a dependent variable the fiscal pressure and as independent variables the level of direct and indirect taxes, the level of public debt, and the annual growth rate of the gross domestic product. Ignoring these economic indicators by developed countries creates adverse effects on state budgets by creating financial deficits. In order to restore the optimal levels of budget deficits, it is necessary to implement new budgetary fiscal measures.

\section{Literature review}

The present article is based on the teachings of Murray L. Weidenbaum, one of the great economists of the financial, economic field, who recounted the events of 1968, regarding the tax increases of taxes and duties, due to the rise in public debts and budget deficits. He presented through various specialized articles the negative impact of the fiscal pressure phenomenon on the personal incomes of the citizens, especially on the consumption and saving indicators. It has shown that tax increases, temporary or permanent, produce the effects desired by states but have adverse effects on taxpayers' consumption and investment expenditures, negatively influencing the living standards of taxpayers. Another author (Nguyen, 2020) states in his scientific paper that the role of taxes is an indispensable one of 
the regulatory instruments regarding states' social and economic development, regardless of whether they are part of the group of developed states.

At the same time, a high level of fiscal pressure leads to an increase in the criminal phenomenon in the long run. Bernasconi et al. (2014) showed that an increase in the tax rate increases tax evasion. According to the same study, people's decisions to evade paying taxes depend on how they adapt to the level of fiscal pressure. In an era characterized by high capital mobility, abuses in the global financial system make it difficult to collect taxes and enforce the law. Tax revenues can help governments finance development and reduce dependence on foreign aid, which is why preventing and combating fraud has a critical role to play. In recent years, the intra-community VAT (value-added tax) system has been misused by new types of tax fraud, such as the so-called intra-community fraud scheme (MTIC), as well as fraud carousel. These types of economic crime bring losses of billions of VAT revenue to the E.U. Member States each year, including the Union. In 2015 alone, carousel fraud has led to losses of about 50 billion euros (European Parliament, 2018).

In his scientific article from 2016, Ruesga presents that fiscal pressure is widespread worldwide and not exclusively for a particular country or continent, which is under the sign of various limitations of government programs in different states.

Regarding the concept of fiscal policy, the author Zacary reports in 2014, in the literature as "the set of financial decisions that the state adopts to ensure the financial resources necessary to perform its duties." Regarding the economic instruments for limiting the increase of public debt levels, we find in the literature authors (Mara, 2011) who assume that a correct analysis of public spending, taxation levels, and loans can positively influence public debt.

Regarding the indicator used in this study, we find in the literature an empirical study conducted on a sample of 21 states, which stated that financial systems and economic growth have an adverse correlation. (Arnold, 2008) The empirical study concluded that a one-unit increase in the different tax rates of different taxes (direct, indirect) could positively influence economic growth only if progressive tax rates are used in productive areas. He also said that a high level of annual GDP growth could increase tax rates. In support of those mentioned in the literature (Vasiliauskaitè \& Stankevičius, 2009), they found a significant and positive interaction between the two indicators in the study they conducted with tax systems and growth data. Positive outcomes on cointegration between growth rate and fiscal burden have been consistent in the literature with studies written by (Sconac 2021), (Zachary 2014) for Zimbabwe, and (Matloja 2016) for South Africa.

Several scientific and empirical studies showed that general fiscal pressure is treated with different indicators such as direct taxes, indirect taxes, public debt, living standards, gross domestic product, and corruption rates. Many authors have concluded that when governments observe a very high level of overall fiscal pressure, they tend to reduce tax burdens (Romano, 1993; Chaney et al., 2002; Eaton and Nofsinger, 2004; Butu et al., 2020, Chen, 2021).

\section{Shared analysis of the determinants of the fiscal pressure phenomenon}

The phenomenon of fiscal pressure is essentially a macroeconomic concept, found actively in all states, which is not classified as a tax, being a purely quantitative 
phenomenon, macroeconomic (corresponds to the measure of fiscal pressure level), and microeconomic, if we relate it to the income of each citizen.

Table 1 presents the general fiscal pressure in the developed countries, starting with 1995.

Table 1: Level of general fiscal pressure- Percentage of GDP

\begin{tabular}{|l|l|l|l|l|l|l|}
\hline & $\mathbf{1 9 9 5}$ & $\mathbf{2 0 0 0}$ & $\mathbf{2 0 0 5}$ & $\mathbf{2 0 1 0}$ & $\mathbf{2 0 1 5}$ & $\mathbf{2 0 2 0}$ \\
\hline European Union & 40,5 & 41,1 & 39,7 & 39,1 & 40,9 & 41,4 \\
\hline Denmark & 48,2 & 48,6 & 49,4 & 46,3 & 47,3 & 47,3 \\
\hline Finland & 45,1 & 46 & 42,2 & 40,7 & 43,7 & 41,9 \\
\hline Germany & 40,8 & 42 & 39,1 & 38,8 & 42,1 & 41,9 \\
\hline Sweden & 46,3 & 49 & 47 & 43,4 & 43,2 & 43,6 \\
\hline Spain & 46,3 & 49 & 47 & 43,4 & 43,2 & 43,6 \\
\hline France & 43,9 & 45 & 44,4 & 44,2 & 44,7 & 44,5 \\
\hline Luxembourg & 37,4 & 38,6 & 39,3 & 38,9 & 38,4 & 40 \\
\hline
\end{tabular}

Source: own calculation based on AMECO data accessed on 19.10.2021

As the literature shows, we can see that the general level of fiscal pressure, compared to the average general level of the European Union, is higher in developed countries. One of the differences between developed and developing countries is that even though they have a higher level of pressure than the general average of the European Union, the living standards are much higher due to fiscal policies correctly adopted and implemented. We can see that Denmark has been at the top of the rankings since 1995, with an average level of general fiscal pressure in the period $1995-2020$ of $47.85 \%$. We can see that, at the end of 2020, after 25 years,

Luxembourg occupied the first place of the ranking for the first time, with a percentage of $47.5 \%$. The state with the lowest level of fiscal pressure is the Spanish state, with an overall average level of fiscal pressure of $34.5 \%$.

In Table 2: Direct taxes - Percentage of GDP, we present the level of direct taxes for the seven states analyzed compared to the average level of the European Union.

Table 2: Direct taxes - Percentage of GDP

\begin{tabular}{|l|l|l|l|l|l|l|}
\hline & $\mathbf{1 9 9 5}$ & $\mathbf{2 0 0 0}$ & $\mathbf{2 0 0 5}$ & $\mathbf{2 0 1 0}$ & $\mathbf{2 0 1 5}$ & $\mathbf{2 0 2 0}$ \\
\hline European Union & 11,8 & 12,9 & 12 & 11,7 & 12,7 & 13,1 \\
\hline Denmark & 29,9 & 29,3 & 30,3 & 28,5 & 30,6 & 30,7 \\
\hline Finland & 16,8 & 20,4 & 16,9 & 15,4 & 16,5 & 15,9 \\
\hline Germany & 11,9 & 12,7 & 10,9 & 11 & 12,3 & 12,8 \\
\hline Sweden & 18,9 & 21,3 & 21 & 18,1 & 18,3 & 18,2 \\
\hline Spain & 9,5 & 9,7 & 10,8 & 9,1 & 9,9 & 11,2 \\
\hline France & 8 & 11,8 & 11,3 & 11,2 & 12,7 & 13,3 \\
\hline Luxembourg & 14,7 & 14,2 & 13,7 & 14,3 & 14,3 & 15,7 \\
\hline
\end{tabular}

Source: own calculation based on AMECO data accessed on 19.10.2021 
We can see that the level of direct taxes for developed countries is significantly higher than the average level of the European Union. This time, Denmark is in first place with the highest level of direct taxes for the whole analyzed period. France and Spain have a relatively low level of tolerability of direct taxes for the characteristics of developed countries, both being close to the average level of the European Union.

The fiscal structure of the direct taxes included in the analysis consists of income taxes (including that of individuals), profit tax, dividend tax, micro-enterprise tax, without considering taxes on salaries or social contributions.

Next, we present in Table no.3 Indirect taxes - Percentage of GDP, the value of indirect taxes, percentage of GDP compared to the average level of the European Union.

Table 3: Indirect taxes - Percentage of GDP

\begin{tabular}{|l|l|l|l|l|l|l|}
\hline & $\mathbf{1 9 9 5}$ & $\mathbf{2 0 0 0}$ & $\mathbf{2 0 0 5}$ & $\mathbf{2 0 1 0}$ & $\mathbf{2 0 1 5}$ & $\mathbf{2 0 2 0}$ \\
\hline European Union & 12,5 & 13,3 & 13,8 & 112,9 & 13,5 & 13,3 \\
\hline Denmark & 16,9 & 16,7 & 17,4 & 16,2 & 16,3 & 15,8 \\
\hline Finland & 13,6 & 13,4 & 12,6 & 12,9 & 14 & 13,8 \\
\hline Germany & 10,4 & 10,8 & 10,4 & 10,9 & 10,8 & 10,4 \\
\hline Sweden & 21,2 & 22,4 & 22,4 & 22 & 21,5 & 21,7 \\
\hline Spain & 10 & 11,3 & 12,1 & 9,9 & 11,7 & 11,2 \\
\hline France & 12,3 & 13,1 & 11,9 & 12,7 & 16,2 & 16,4 \\
\hline Luxembourg & 11 & 13,2 & 13,4 & 12,4 & 11 & 11 \\
\hline
\end{tabular}

Source: own calculation based on AMECO data accessed on 19.10.2021

Regarding the level of fiscal pressure due to indirect tax rates, we see that most developed countries are below the average level of the European Union.

According to the literature, this result is an essential feature of budgetary policies adopted by developed countries. Only Sweden (with an average of $21.86 \%$ ), Denmark, and, in the last ten years, France have maintained a high level of the tax burden in terms of indirect taxes, above the average level of the European Union.

Table no. 4: Gross public debt- Percentage of GDP, presents the relative level of public debt in the seven developed countries of the European Union.

Table 4: Gross public debt - Percentage of GDP

\begin{tabular}{|l|l|l|l|l|l|l|}
\hline & $\mathbf{1 9 9 5}$ & $\mathbf{2 0 0 0}$ & $\mathbf{2 0 0 5}$ & $\mathbf{2 0 1 0}$ & $\mathbf{2 0 1 5}$ & $\mathbf{2 0 2 0}$ \\
\hline European Union & - & 66,2 & 67 & 80,6 & 86,6 & 91,8 \\
\hline Denmark & 73,1 & 52,4 & 37,4 & 42,6 & 39,8 & 42,2 \\
\hline Finland & 55,2 & 42,5 & 39,9 & 46,9 & 63,6 & 69,2 \\
\hline Germany & 54,9 & 59,1 & 67,3 & 82,4 & 72,2 & 69,8 \\
\hline Sweden & 68,7 & 50,3 & 48,7 & 38,1 & 43,7 & 39,9 \\
\hline Spain & 61,5 & 57,8 & 42,4 & 60,5 & 99,3 & 120 \\
\hline France & 56,1 & 58,9 & 67,4 & 85,3 & 95,6 & 115 \\
\hline Luxembourg & 9,8 & 7,5 & 8 & 20,2 & 22 & 24,9 \\
\hline
\end{tabular}

Source: own calculation based on AMECO data accessed on 19.10.2021 
We can see that since 1995 Denmark, Sweden and France have had a relatively high level of public debt. However, the ranking of the analyzed developed states has changed with time. In 2010, Germany and France managed to borrow $85.3 \%$ and $82.4 \%$ of GDP. However, in 2015, we see that Germany managed to take into account the degree of public indebtedness of $60 \%$ indicated by the Maastricht Treaty and the recommendations of the Council of Europe. Instead, the Spanish state managed to surprise the European Council with a degree of indebtedness of $99.3 \%$ by 38.8 percent more than in 2010 . Finally, we note that in 2020,12 years after the economic crisis, Spain and France failed to take into account the recommendations of the Council of Europe, recording significant negative values of $120 \%$ and $115.7 \%$. Denmark, Sweden, and Luxembourg are the states that manage to be below the maximum indebtedness threshold recommended by the Maastricht Treaty in 2020.

\section{Methodology}

Panel regression is a modeling method adapted to the data of each panel. It is also called cross-sectional data or longitudinal data. This type of panel regression is widely used in econometrics, where the behavior of statistical units (i.e. panel units) is tracked over time. These units can be states, companies, countries, etc. Panel regression allows control for both the effect of the unit under consideration and the effect of time in estimating the regression coefficient.

The statistical form of the regression model with panel data has the following representation:

TAX_BURDEN $=\mathrm{C}(1)+\mathrm{C}(2)^{*}$ INDIRECT_TAXES + C(3)*DIRECT_TAXES + $\mathrm{C}(4)^{*} \mathrm{GDP}$ _GROWTH_ANNUAL__ $+\mathrm{C}(5)^{\star} \mathrm{GROSS}$ _PUBLIC_DEBT

\subsection{Sample and data}

In this study, we decided to use as a methodology the multiple regression model with panel data, taking as a dependent variable the general level of fiscal pressure, and considering as independent variables, the level of indirect taxes (\% GDP), public debt (\% GDP) and GDP growth rate. The analysis is performed at some developed countries in the European Union, Sweden, Finland, Denmark, Luxembourg, France, Spain, Germany. The period analyzed within the multiple regression is from 1995 to 2018, approximately 23 years, with an annual frequency of the analyzed data. The database was taken over from the World Bank, AMECO, and Transparency International.

Table 5: Variables used

\begin{tabular}{|l|l|}
\hline Symbol & Description \\
\hline INDIRECT_TAXES & Indirect taxes \\
\hline DIRECT_TAXES & Direct taxes \\
\hline GDP_GROWTH_ANNUAL__ & Gross Domestic Product Growth Rate \\
\hline GROSS_PUBLIC_DEBT & Public Debt \\
\hline TAX_BURDEN & Fiscal pressure \\
\hline
\end{tabular}

Source: Made by the author 
With the help of multiple regression with panel data, we want to analyze whether we can claim that these variables significantly influence each other.

\subsection{Results and discussion}

Table 6: Regression Results

\begin{tabular}{|l|l|l|l|l|}
\hline Variable & Coefficient & Std. Error & t-Statistic & Prob. \\
\hline C & 40.58260 & 0.646969 & 62.72723 & 0.0000 \\
\hline INDIRECT_TAXES & 0.055416 & 0.012042 & 4.601980 & 0.0000 \\
\hline DIRECT_TAXES & 0.018486 & 0.011841 & 1.561242 & 0.1204 \\
\hline GDP_GROWTH_ANNUAL_ & -0.034861 & 0.140939 & -0.247348 & 0.8050 \\
\hline GROSS_PUBLIC_DEBT & -0.011492 & 0.001830 & -6.279144 & 0.0000 \\
\hline \multicolumn{5}{|l|}{} \\
\hline R-squared & 0.202711 & F-statistic & 10.36072 \\
\hline Adjusted R-squared & 0.183146 & Prob(F-statistic) & 0.000000 \\
\hline Durbin-Watson stat & 0.055843 & & \\
\hline
\end{tabular}

Source: own processing in Eviews 7.1

In Table 6, Regression Results, following the analysis, it was found that the value of the determination ratio underlines and highlights the fact that $20.27 \%$ of the variance of the general level of fiscal pressure is reproduced by the multiple regression model made above.

The model equation is as follows:

TAX_BURDEN $=40.5825961231+0.0554163748857^{*}$ INDIRECT_TAXES + $0.0184862808898^{*}$ DIRECT TAXES

$0.0348608418224^{*}$ GDP GROWTH ANNUAL

$0.0114922596466^{*}$ GROSS_PUBLIC_DEBT

It is highlighted that the probability attached to the Fisher test (F-statistic) is visibly lower than the significance threshold of $5 \%$, which demonstrates that the validity of the multiple regression model is achieved.

As we can see, as the level of indirect taxes increases by one unit, the general level of fiscal pressure will increase by 0.055 percentage points, provided that the other analysis factors remain constant.

As direct taxes increase by one unit, the general level of fiscal pressure will increase by 0.018 percentage points.

Also, as the growth rate of the gross domestic product increases by one unit, the level of fiscal pressure will decrease by 0.034 percentage points, provided that the other factors remain constant.

At the same time, as the level of public debt increases by one unit, the level of fiscal pressure will decrease by 0.011 percentage points, provided that the other factors remain constant.

Next, we tested the normality as well as the homoscedasticity of the residues. 
Table 7: Residual homoscedasticity testing

\begin{tabular}{|c|c|c|c|c|}
\hline & \multicolumn{2}{|l|}{ Value } & $\mathrm{df}$ & Probability \\
\hline Likelihood ratio & \multicolumn{2}{|l|}{7.825175} & 7 & 0.3483 \\
\hline Restricted LogL & \multicolumn{2}{|l|}{-477.0647} & 163 & \\
\hline Unrestricted LogL & \multicolumn{2}{|l|}{-473.1521} & 163 & Unrestricted LogL \\
\hline Variable & Coefficient & Std. Error & t-Statistic & Prob. \\
\hline $\mathrm{C}$ & 40.42510 & 0.596290 & 67.79436 & 0.0000 \\
\hline INDIRECT_TAXES & 0.063404 & 0.011456 & 5.534472 & 0.0000 \\
\hline DIRECT_TAXES & 0.010770 & 0.010292 & 1.046462 & 0.2969 \\
\hline GDP_GROWTH_ANNUAL_ & -0.045429 & 0.138493 & $\begin{array}{l}- \\
0.328022\end{array}$ & 0.7433 \\
\hline GROSS_PUBLIC_DEBT & -0.011183 & 0.001608 & $-\overline{6.954128}$ & 0.0000 \\
\hline \multicolumn{5}{|c|}{ WeightedStatistics } \\
\hline R-squared & 0.241432 & F-statistic & \multicolumn{2}{|l|}{12.96961} \\
\hline Adjusted R-squared & 0.222816 & $\begin{array}{l}\text { Prob(F- } \\
\text { statistic) }\end{array}$ & \multicolumn{2}{|l|}{0.000000} \\
\hline Durbin-Watson stat & 0.054272 & & & \\
\hline \multicolumn{5}{|c|}{$\begin{array}{l}\text { Unweighted } \\
\text { Statistics }\end{array}$} \\
\hline R-squared & 0.195429 & $\begin{array}{l}\text { Mean } \\
\text { dependent } \\
\text { var }\end{array}$ & \multicolumn{2}{|l|}{42.09643} \\
\hline Sum squared resid & 2905.964 & $\begin{array}{l}\text { Durbin- } \\
\text { Watson } \\
\text { stat }\end{array}$ & \multicolumn{2}{|l|}{0.054272} \\
\hline
\end{tabular}

Source: Author's contributions using EViews 7.1

The null hypothesis of this test implies the existence of homoscedasticity at the residue level, while the alternative hypothesis implies heteroskedasticity. The probabilities of the test, which are higher than the significance threshold of $5 \%$, underline the fact that the null hypothesis is accepted, which means that at the level of disturbing factors, the presence of homoscedasticity is noticed.

Next, we will test whether or not the perturbations belong to a normal distribution, using the Jarque-Bera test. Under the null hypothesis, the errors belong to a normal distribution, while the alternative hypothesis suggests that the errors are not part of a normal distribution. 
Table 8: Homoskedasticity testing

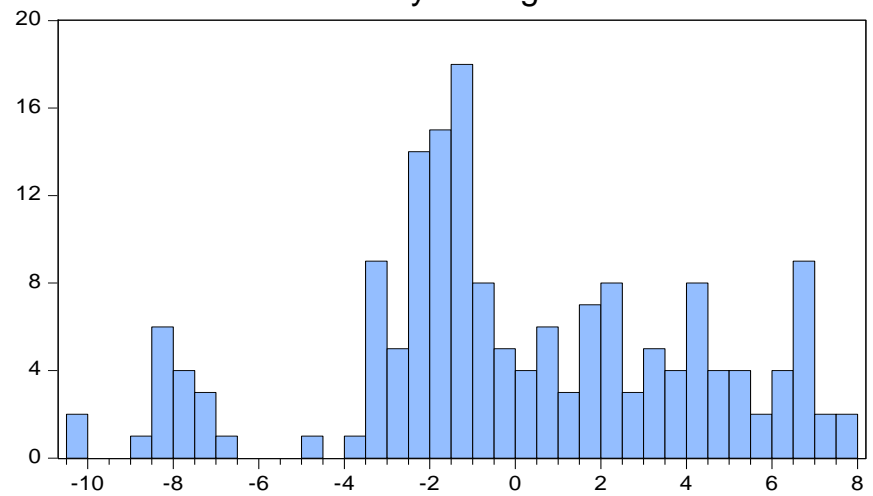

Series: Standardized Residuals Sample 19952018

Observations 168

Mean $\quad 4.04 \mathrm{e}-15$

Median $\quad-0.764265$

Maximum 7.666893

Minimum $\quad-10.38478$

Std. Dev. $\quad 4.152527$

Skewness $\quad-0.215654$

Kurtosis $\quad 2.710339$

Jarque-Bera 1.889508

Probability $\quad 0.388775$

Source: own processing in Eviews 7.1

The Jarque-Bera test is used in econometrics to test whether or not errors are part of a normal distribution. A perfectly normal distribution situation implies the skewness value equal to 0 and the kurtosis value equal to 3 . As long as these two reference values exceed the specified threshold, the obtained errors tend to no longer belong to a customarily destroyed distribution. The default test hypothesis is that the errors are part of a normal distribution. Referring to the significance threshold of $5 \%$, it is observed that the probability of the Jarque-Bera test is higher than the significance threshold of $5 \%$. This fact proves that the test's null hypothesis is admitted, so the errors are part of a normal distribution in the analyzed model.

\section{Conclusions}

Taxing citizens and collecting revenue efficiently is a cornerstone of any governess's training and survival.

The ability to tax citizens and collect revenue efficiently is a cornerstone of the formation and survival of any state and the basic principle of a successful fiscal policy.

According to the literature, it has been found that tax increases hurt economic growth in most states. However, in developed countries, the high level of taxes does not affect economic growth because developed countries have created a long-term environment conducive to new investment areas and are constantly attracting new investors.

Within fiscal policies, an important goal for developing their capacity is to accelerate economic growth, through various taxation systems, without creating a real tax burden on the shoulders of cities because they realize this taxation at a time. Economically favorable. An essential feature in the developed state of fiscal policies is the flexibility of policies, which manages to perfectly harmonize two strategic objectives, between controlling inflation and economic growth.

The final results show that direct and indirect taxes influence the evolution of fiscal pressure. There is a direct relationship between the fiscal pressure and the two variables in the regression model. 
Also, the growth rate of gross domestic product and government debt as the unit increases by one level decreases general fiscal pressure.

In conclusion, the seven states analyzed in the article will have progressive taxes on direct taxes, to the detriment of indirect taxes, and in general, a level of public debt below the average level of the Union.

At the same time, through the multiple regression performed, it was found that we cannot sustain a significant influence between the variables.

Finally, we emphasize that a critical feature in the development of any state depends on the ability of the tax system to generate annual economic growth. This can be achieved through their ability to turn savings into investment resources, to provide support through administrative reforms aimed at start-ups, and to provide financial peace to companies in times of stalemate.

\section{References:}

1. Adriana Elena Porumboiu, Ionela Butu, Raluca Ghetu, Petre Brezeanu (2020) REVERSE CHARGE AND VAT GAP - A MECHANISM TO TACKLE INTRACOMMUNITY VAT FRAUD, Strategica - International Academic Conference, vol. VIII, nr. I, pg. 396-412, ISSN 2734-746X;

2. Arnold, J. M. (2008). Do Tax Structures Affect Aggregate Economic Growth? OECD Economics Department Working Papers,1-29, Do Tax Structures Affect Aggregate Economic Growth?: Empirical Evidence from a Panel of OECD Countries I READ online (oecd-ilibrary.org).

3. Bernasconi, M., Corazzini, L., \& Seri, R. (2014). Reference dependent preferences, hedonic adaptation, and tax evasion: Does the tax burden matter? Journal of Economic Psychology, 103-118, DOl:10.1016/j.joep.2013.01.005;

4. Brezeanu P. Fiscalitate. Concepte. Metode. Practici, Editura Economică, Bucureşti, 1999;

5. BREZEANU, (2009) P.Fiscalitate: concepte, teorii, politici şi abordări practice. Bucureşti: Ed. WoltersKluwer;

6. Chaney, B. A. (2002). The effect of fiscal stress and balanced budget requirements on the funding and measurement of state pension obligations. Journal of Accounting and Public Policy, 287-313, https://EconPapers.repec.org/RePEc:eee:jappol:v:21:y:2002:i:4-5:p:287-313;

7. Charles E. McLure Jr."Taxation".Britannica. Retrieved 3 March 2015.

8. Chen, G. M. (2021). Costs and liabilities of U.S. public pension systems in a lowreturn environment. Journal of Pension Economics and Finance, 20(2), pages 169186, DOI: 10.1017/s147474721900043x;

9. Eaton, T. V. (2004). The effect of financial constraints and political pressure on the management of public pension plans. Journal of Accounting and Public Policy, 161-189, The effect of financial constraints and political pressure on the management of public pension plans - ScienceDirect;

10. I Talpoş, C Enache (2001), Carta Europeană a Autonomiei Locale, Timisoara; 11. Mara, E. \&. (2011). Fiscal Policy Impact on Inflation Volatility in Romania in The. Finante - provocarile viitorului/Finance - Challenges of the Future., 1 (13), 181-187, 013-24.pdf (ucv.ro).

12. Matloja, L. M. (2016). Changes in the optimal tax rate in South Africa. Munich Personal RePEc, pages 1-20, https://mpra.ub.uni-muenchen.de/id/eprint/74342. 
13. McNabb, K.; LeMay-Boucher, Ph. (2014): "Tax Structures, Economic Growth and Development", Working Paper 22, www.ictd.ac, pp. 1- 3;

14. Nguyen uu Cung and Liu Hua (2013). "Tax Burden and Foreign Direct Investment: Theor and practice in Vietnam". Advances in Management and Applied Economics, vol., no., pp.85-103;

15. Nguyen uu Cung and Nguyyen Ti ong Nhung (2020). ," Impact of Economic Freedom and Corruption Perceptions Index on Foreign Direct Investment in Vietnam". European Scientific Journal, Vol 16, No. 7, 2020, pp:25-37;

16. Roberta Romano (1993). PUBLIC PENSION FUND ACTIVISM IN CORPORATE GOVERNANCE RECONSIDERED, COLUMBIA LAW REVIEW, Public Pension Fund Activism in Corporate Governance Reconsidered (yale.edu);

17. Ruesga, J. V. (2016). Economic sustainability and possibilities of action for the states, in the case of monetary integration: some notes for reflection, https://www.inderscienceonline.com/doi/abs/10.1504/PIE.2016.078078;

18. Sconac, N. K. (2021). Tax burden and economic growth in Lesotho: An estimate of the optimal tax burden. GrowingScience, 525-534, DOI: 10.5267/i.ac.2021.1.006.

19. Vasiliauskaitè, A., \& Stankevičius, E. (2009). ax burden management and GDP growth: A case of E.U. countries. Ekonomika ir vadyba, 14, 202-209, https://www.lituanistika.lt/content/22347.

20. Zachary, T. \&. (2014). Causal Relationship between Government Tax Revenue Growth and Economic growth: A case of Zimbabwe. Journal of Economics and Sustainable Development., 40-59, http://hdl.handle.net/11408/1225. 